\title{
The dissociative identity disorder (DID). How to proceed in case of crime committed under mental illness
}

\author{
Alexa Fabris \\ Unitelma Sapienza University of Rome, Doctor in administration and security sciences, resume of investigation and \\ security, Italy
}

\begin{abstract}
Dissociative identity disorder means a mental pathology that involves the normal interaction of the most important psychic processes of the human mind, bringing the one who is afflicted by it, to be no longer fully aware of himself and his actions. Among the various mental disorders within the DSM is perhaps the most specific to damage the conscious side of a person. The concept of awareness is very difficult to internalize and this is often taken for granted. Those who are unaware of their actions, if they commit a crime, are declared not imputable and for them a rehabilitative path opens up within structures for the execution of the security measures suitable for their psychiatric condition, these institutes are called R.E.M.S.
\end{abstract}

\section{RIASSUNTO}

Per disturbo dissociativo dell'identità si intende una patologia mentale che coinvolge la normale interazione dei più importanti processi psichici della mente umana, portando colui che ne è afflitto a non essere più pienamente consapevole di sé stesso e delle proprie azioni. Tra i vari disturbi mentali all'interno del DSM è forse quella più specifica a ledere il lato consapevole di una persona. Il concetto di consapevolezza è molto difficile da interiorizzare e per questo molte volte viene dato per scontato. Coloro che sono inconsapevoli delle proprie azioni, qualora commettano un reato, vengono dichiarati non imputabili e per loro si apre un percorso riabilitativo all'interno di strutture per l'esecuzione delle misure di sicurezza adatto alla loro condizione psichiatrica, questi istituti sono detti R.E.M.S.

\section{RESUMEN}

Nos referimos al trastorno de identidad disociativo como una patología que afecta a la interación normal de los procesos psíquicos más importantes de la mente humana, llevando al que está afectado por ella a no ser consciente de sí mismo y de sus acciones. Entre los diversos trastornos más conocidos del DSM es, quizás, el más específico para dañar el lado consciente de una persona. El concepto de conciencia es muy difícil de internalizar y esto a menudo se da por hecho. Aquellos que desconocen sus acciones, si cometen un delito, son declarados no imputables y para ellos se abre un camino de rehabilitación dentro de las estructuras para la ejecución de las medidas de seguridad adecuadas para su condición psiquiátrica, estos institutos se llaman R.E.M.S.

\section{Introduction}

Each of us tries to define himself in the world as a person, building an identity in itself. We start in the early age from when we are children through values and behavioral models that are transmitted to us by our parents. At a later time we deal with reality beyond family, where there are social rules to follow that allow us to integrate and stay involved in the society. In all this our cognitive path, the personality is never one alone. The set of our behaviors is infinite, there are a series of possible variables that we then consciously choose to use to cope with the different needs of life. The key factor to keep in mind is that each of us rules all this set of ways of being and they alternate driven by our awareness in the different circumstances of life. The man is the only living being in the world able to reach the highest level of awareness, or rather, understanding. The definition of our mental health is our level of self awareness.

\section{Billy Milligan's Case}

Milligan's case has a significant importance in the United States judicial history in the late 70 s. The judge gave rise to a precedent and for this reason it was not easy for him to make a decision. For the first time, even though crimes such as kidnapping, robbery and the rape of three female students from Ohio University got acknowledged to the accused, the jury acquitted him because he suffered from a mental pathology known as DID, which did not make him aware of his actions. His disorder was recognized under oath of four psychiatrists and a psychologist. With this sentence the DID was acknowledged as a real pathology, and not a simple neurosis as it had been considered up to that moment. As a matter of facts, the cases of DID prior Milligan's case were developed outside of APA (American Psychological Association). The APA will recognize this disorder only in 1980. Billy's dissociative identity disorder got worse when he was 9 years old, when he started to be physically and sexually abused from his stepfather, until reaching 24 personalities.

The first rehabilitation project by Dr. Harding was meant to help and prepare Billy for the trial, meanwhile after the trial the rehabilitation of Doctor Caul was mainly thought to re-educate him in social life. Following the trial, Billy was transferred to the Athens Mental Health Center to receive appropriate treatments. The therapy was destined to a "fusion" and therefore to lead the young Billy to become aware and self-controlled in order to be declared free and not dangerous for society. After a meticulous work, the figure of the "Master" was revealed, the fusion of all personalities into one, 
including the original one. Only the Master could connect all of Billy's memories. From then on Billy obtained permits for his "clinical successes", he was allowed to leave the ward first accompanied, then alone, as long as all the movements were notified. After a while he was allowed to leave the building to check his reaction to external stirrings to the strong prejudice of the people around him. The first attempts went well, but the sequel was not easy at all. Many pressures were initiated by the press solicited by the counterpart's lawyers.

All this matter led Billy to a suicide attempt which made the judge taking the decision to transfer him to a criminal asylum the Lima State Hospital, losing in this way all the care taken up that moment, with inevitable loss of progress he made. After two and a half years spent in three high-security hospitals, Billy was brought back to Athens. This moving happened thanks to a trial to which all the doctors and lawyers who had followed Billy up until that moment gave their testimony, so he could resume the appropriate treatment to his situation. In 1991 he was declared no more dangerous and free to go. In 2012 he was diagnosed with a very aggressive type of sarcoma (malignant tumor ). Milligan refused every form of treatment, and he was then admitted to the private hospital in Columbus, where he died on December 12, 2014, at the age of 59.

\section{The dissociative identity disorder}

The dissociative identity disorder (DID) is a particularly rare but decisive pathology in the awareness' lesion. According to the DSM, the dissociative disorders are characterized by an upheaval and/or discontinuity in the normal integration of consciousness, memory, identity, emotion, perception, representation of the body and behavior. This abnormal integration can potentially compromise every area of psychological functioning, experienced as an intrusion into the individual's awareness and behavior. The cause is almost universally associated with a prior history of significant trauma, most of the time occurring during early childhood. A child in the development stage cannot explain certain situations and therefore his mind seeks an answer to react to that unique situation in order to protect himself.

The symptoms of DID generally include panic attacks, phobias and borderline personality disorders, which can lead to suicidal thoughts.

The DID has three main characteristics as defined by the DSM:

- The main characteristic of this psychopathological condition is the interruption of identity. The presence in the person of two or more distinct personality states, each of them with its own relatively stable ways of perceiving, relating and considering the environment and the self.

- The second characteristic of the disorder is represented by amnesias of excessive flow in order to be explained as normal forgetfulness.

- Associated characteristics: The individual affected by DID may or may not be aware of the different identities"

\section{From the medical to the criminology point of view}

The recommended treatment for the treatment of Dissociative Identity Disorders is psychotherapy, with the main purpose of leading the patient back towards a better integrated functioning. The therapist promotes the idea that all alternative identities represent attempts of adjustment to face or handle the difficulties encountered by the patient, and the idea acts by helping identities to know one another, accepting themselves as legitimate parts of the self and negotiating to resolve their conflicts. The medical chore offers treatments in addition to individual psychotherapy, where the patients can benefit from. They are specific interventions such as dialecticalbehavioral therapy, desensitization and re-elaboration through ocular movements, sensorimotor psychotherapy, group therapies.

The dialectic-behavioral therapy is a treatment with integrated cognitive-behavioral orientation that involves the strengthening of those skills in which the patient is lacking, in particular the regulation of his intense negative emotions, and it seems to be particularly suitable for people with self-injurious and suicidal acts. The treatment's foundation is helping the patients to minimize the behaviors that are dangerous to themselves or others, and the ones that make them vulnerable to victimization by others.

These behaviors include suicidal and parasuicidal behaviors, substance and alcohol abuse, violent relationships, eating disorders, violence or assaults and high-risk behaviors. The desensitization and reconditioning of the ocular movements are very useful in modifying distortions in the representation of the self, simplifying the integration. It allows the patient to approach the pain safely, allowing the temporary deactivation of the attachment system and the consequent activation of an exploratory attitude. The Sensorimotor psychotherapy helps the patient recover the ability to regulate those uncontrolled states of the body that contribute to dissociation. But if there was a crime committed by a person suffering from a mental disorder, in addition to medical knowledge aimed at intervening on the pathology, clinical criminology plays an important role in the study of crime and analogously to medicine establishes a diagnosis, prognosis and treatment. The diagnosis aims to reconstruct the factors and conditions that led to the genesis and execution of the crime. The prognosis has the fundamental purpose of evaluating the greater or lesser social dangerousness of an individual, therefore it estimates the greater or lesser probability of social recovery for that individual, a forward-looking model that has had considerable success in the past is the developed one by the spouses Eleanor and Sheldon Glueck.

And at the end a detention treatment is established to be associated to psychotherapy, this type of intervention in Italy is made through the R.E.M.S.

\section{Analysis and conclusions}

My research collects the opinion of a sample of the population, in this case the city hall of Maniago, where there is one of the 23 R.E.M.S. The selected sample lives nearby the structure. I have organized a questionnaire with the purpose focused to indicate whether the ordinary citizen agrees with what our law says in the articles 88 of our penal code. Or even better, if they do not agree, understanding the motivations. The questionnaire is divided into 3 parts. In the first part I collect information regarding the general opinion of the sample interviewed on the guests of the structure. We start from the perception that we have of an individual affected by the disease until we get to the perception of the same individual who, however, goes further, towards a serious crime. In the second part I collect opinions on the hosting structure. In these first two parts I collect the general opinions of some people, but in the third part I get the decisive answer.

The question I ask is: Do you think it is right that the penalty for a crime is taken and measured on the basis of a possible mental illness of the guilty? More specifically, do you believe that those people suffering from a mental illness must serve the sentence in a structure like R.E.M.S rather than in a prison? 
Different motivations were collected from this question and they are divided into two distinct ways of thought.

The pros R.E.M.S. affirms (I textually quote one of the answers given): "I think it is correct that the penalty for a crime committed by a person with mental illness is judged differently from a crime committed by a person clinically sound of mind, usually a person suffering from mental disorders does not have the same perception of reality to different inputs and external stirrings, which often can be overstated, and uncontrollable... These structures are certainly more suitable for them, they pay more attention to their problem without forgetting the damage that has been done, where they still are somehow punished with limitations and imprisonment in certain spaces for a certain period of time".

Article 88 (penal code) "imputability is excluded where the accused committed the act through infirmity in such a state of mind as to exclude the capacity of understanding or wanting"

The cons R.E.M.S. instead affirms (I textually quote one of the answers given): "In my opinion I think it is not fair because it would be judged by the action itself, not the condition. The law should declare an equal punishment for everyone when the cases are serious."

And it is exactly on this last thought that we linger to understand that the disagreement gives rise to a prejudice not regarding the structure but regarding the person, and for what reason does this prejudice exist? A distinction is made between "action" and "condition" of an individual. But it is not possible to divide these two factors because they are both part of our conscious side. There is a normal ignorance of the complexity of the human mind and of its structure. A complete diagnosis is made when the clinical criminology department examines a crime while also studying the awareness part of the patient.

To do so are considered 3 factors: at fault, victim and relationship between the two. And 4 moments prior the crime.

Correspondence: Alexa Fabris.

E-mail: a.fabris@studenti.unitelma.it

Key words: Self awareness; Billy Milligan; DID dissociative identity disorder; R.E.M.S., clinical criminology; criminogenesis; criminal dynamics; victimology;recidivism.

Parole chiave: Consapevolezza; Billy Milligan; DDI disturbo dissociativo dell'identità; R.E.M.S.; criminologia clinica; criminogenesi; criminodinamica; vittimologia; recidiva.

Palabras clave: Consciencia; Billy Michigan; DID desorden de identidad disociativa; REMS; criminología clínica; criminogénesis; dinámicas criminales; victimología; reincidencia.

Received for publication: 15 March 2018.

Revision received: 23 March 2018.

Accepted for publication: 19 April 2018.

This article is distributed under the terms of the Creative Commons Attribution Noncommercial License (by-nc 4.0) which permits any noncommercial use, distribution, and reproduction in any medium, provided the original author(s) and source are credited.

(C) Copyright A. Fabris, 2018

Licensee PAGEPress, Italy

Rivista di Psicopatologia Forense, Medicina Legale, Criminologia

2018; $23: 38$

doi:10.4081/psyco.2018.38
The criminal sciences use as reference two very important concepts to face this study: criminogenesis which is the basic relational situation among the individuals involved; and the criminodynamics that is the evolution of that initial situation until the commission of the crime. Both of them are moments that precede the crime itself, even if the term "criminodynamics" could be mistaken, which it can be understood as the moment that explains the dynamics of crime, where instead is the modus operandi.

Thanks to these two moments the study of the guilty party was possible. The main goal was trying to understand the point of view and so his motivations.

From the beginning of these studies to nowadays the awareness aspects, relational, emotional and the author's psychological aspects can't be ignored in a study of a crime. In other words, we must analyze the guilty, the offender and the relationship between the two. You just can not consider only one of the two factors. It's like they were two distinct sets that share a "relationship", to understand one and the other one you must fuse them together, or at the end the analysis will be incomplete. So we have a victimcentric factor, which is the victim's point of view compared to the offender, and the victim-offender relationship. We have a different prospective for the victim too : the Victimology and Victimization. The first one is about the elements and variables of the victim's life regarding the personality, the way of interacting, the way of being, and previous experiences.

The second one is about the elements and variables that caused the end of the bond with the culprit. These dimensions offer us an understanding of relational dynamics in this way we have a complete view of the situation: awareness of the victim and awareness of the author in relation to the damage caused.

However, there are factors that negatively influence the person's awareness and are therefore taken into consideration to establish the sentence.

An assessment of social danger is due to people with prior checking of infirmity and after the decision of non-imputability or semi-imputability.

This factor determines the possibility of recidivism. When the individual has been declared infirm with total exclusion of the ability to understand and want is undoubtedly socially dangerous, but unlike those with full capacity needs to become aware and then will be applied to him a security measure that provides, currently in Italy, the inclusion in the R.E.M.S., at least until it is declared no longer a danger to himself and others.

The individual will be imprisoned in this structure where he will also follow the rehabilitation phases for his condition. This process, if successful, leads to decriminalization, that is, the reintegration of the guilty party into society, which is the same goal of common prisons.

\section{References}

Keyes D. Una stanza piena di gente. Casa Editrice Nord, 2009.

Biondi M., DSM-5. Manuale diagnostico e statistico dei disturbi mentali. Cortina Raffaello, 2014.

Monzani M., Temi di psicologia giuridica ed investigativa. Libreria universitaria, 2015.

Smith C.M., Retrieving the Soul and retrieving the Sacred. Trafford, 2007.

DSM-5, Manuale diagnostico e statistico dei disturbi mentali. Cortina Raffaello, 2014.

https://www.giustizia.it 